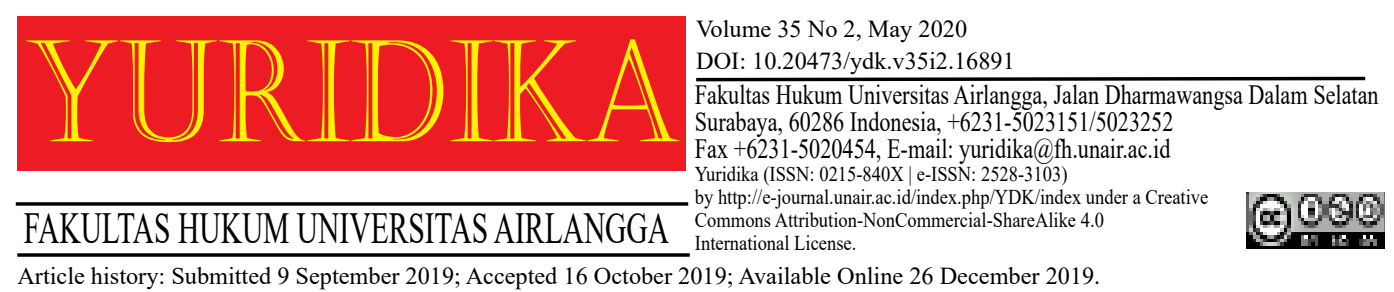

\title{
Indonesia's Patent Policy on the Protection of Genetic Resources Related Traditional Knowledge: Is it a Synergy to Fulfill the TRIPs Agreement and CBD Compliance?
}

\author{
Nurul Barizah \\ nurul.barizah@fh.unair.ac.id \\ Universitas Airlangga
}

\begin{abstract}
This research analyses the compatibility of Indonesian Patent Act with the Trade related Aspect of Intellectual Property Rights (TRIPs) Agreement and the Convention on Biological Diversity (CBD) dealing with Genetic Resources Related to Traditional Knowledge (GRTK). The focus this analyses on whether the new Indonesian Patent Act provides a clear policy on the protection of GRTKF and the development of the biotechnology in Indonesia, particularly on the patentability of genetic resources related inventions, including genes patent. This research found that the new Indonesian Patent Act on GRTK is not only to synergise between the TRIPs Agreement obligation and the CBD compliance, but also adopted patent policies derived from other developed countries particularly in examining the patentability thresholds and exceptions from patentability. Even, in the context of patentability of living organisms, Indonesia adopts a very liberal approach compared to most industrialised countries. This research advises that Indonesian patent policy on GRTK should take into account the richness of this country on biodiversity and the level of biotechnology industry development.

Keywords: TRIPs Agreement; Indonesian Patent Act; Genetic Resources related to Traditional Knowledge; the CBD.
\end{abstract}

\section{Introduction}

Historically, protection of Intellectual Property Rights (IPRs) in Indonesia, including patent, cannot be separated from the membership of this country to the World Trade Organization (WTO) and the ratification of the Agreement on Trade Related Aspects of Intellectual Property Rights including trade in counterfeit 
goods (TRIPs Agreement), ${ }^{1}$ as one of the pillars of the WTO global trade regime. To comply with the TRIPs Agreement, Indonesia has already amended its national IPRs law several times, including its Patent Act. ${ }^{2}$ The most important amendment of this Patent Act was made almost two decades ago by the end of $2001,{ }^{3}$ when the new emerging issues in IPRs on genetic resources and related traditional knowledge (GRTK) received worldwide attention, and were discussed in several international forums and organisations, such as the Intergovernmental Committee on Genetic Resources, Traditional Knowledge and Folklore (IGCGRTKF) of World Intellectual Property Organization (WIPO) and Conference of the Parties (COP) of the Convention on Biological Diversity (CBD), and many others. ${ }^{4}$

But, this Patent Act Number 14 of $2001^{5}$ was developed under the spirit of the TRIPs Agreement to facilitate the liberalization of world trade and to protect IPRs holders by fostering harmonization of patent worldwide. This spirit can be clearly seen in the Preambule of the Act which states that: "in accordance with Indonesia's

${ }^{1}$ World Trade Organization, Agreement on Trade Related Aspects of Intellectual Property Rights (TRIPs) of 1994. Marrakesh Agreement Establishing the World Trade Organization, , Annex 1C, Legal Instruments - Results of the Uruguay Round Vol. 31; 33 I.L.M. 1197, 1201, 15 April 1994 (E (1994).

2 See the Act of the Republic of Indonesia Number 6 of 1989 regarding Patent (State Gazette of the Republic of Indonesia Number 39 Year 1989). as it amended with the Act of the Republic of Indonesia Number 13 of 1997. regarding the Amendment on the Act of the Republic of Indonesia Number 6 of 1989 regarding Patent (State Gazette of the Republic of Indonesia Number 39 Year 1989). Then,Act of the Republic of Indonesia Number 14 Year 2001 regarding Patent (the State Gazette of the Republic of Indonesia Number 109 Year 2001, Supplementary State Gazette Number 4130).

3 This Amendment was passed by the President of the Republic of Indonesia on 1 August 2001 in Jakarta.

${ }^{4}$ Intergovernmental Committee on Genetic Resources, 'Traditional Knowledge and Folklore (IGCGRTKF) of World Intellectual Property Organization (WIPO)' (2000).; Secretariat-WIPO General Assembly, 'Matter Concerning Intellectual Property and Genetic Resources, Traditional Knowledge, and Folklore' (2000). Twenty-Sixth (12th Extraordinary) session, Geneva, 25 September - to 3 October, 2000, Document WO/GA/26/6, para 14. See also the Conference of the Parties (COP) of the CBD, in which Intellectual Property Rights (IPRs) is at the heart of discussion, particularly regarding access to genetic resources, benefit sharing, transfer of technology and innovations and traditional knowledge; See also UPOV, 'Access to Genetic Resources and Benefit Sharing - Reply of UPOV to the Notification of June 26, 2003 from the Executive Secretary of the Convention on Biological Diversity (CBD)', adopted by the Council of UPOV at its thirty-seventh ordinary session on October 23, 2003, 3. See also, the FAO-International Treaty on Plant Genetic Resources (ITPGR) which entered into force on 29 June 2005, in which a most worthy aspect of the Treaty was the establishment of a multilateral system of access and benefit sharing.

${ }^{5}$ The Act of the Republic of Indonesia Number 14 Year 2001 about Patent (the State Gazette of the Republic of Indonesia Number 109 of 2001, Supplementary State Gazette Number 4130). 
ratification on the international agreements, the ever growing development of technology, industry and trade, a patent law that can provide appropriate protection for investors is needed": Then, the Explanatory Memoranda of the Indonesia Patent Act of 2001, part I, paragraph 3 clearly states that the basic rational for this amendment, because there are several aspects of the TRIPS Agreement which are not fully implemented in the old Patent Act.

On that time, a number of biodiversity rich developing countries ${ }^{6}$ amended their laws to synergize between the TRIPs Agreement and $\mathrm{CBD}^{7}$ objectives. For examples, Indian and Brazilian legislative frameworks accommodate their national interests by requiring deposit of biological material with specifications to the depositary institutions and disclosing the source and geographical origin of the biological material used in the invention, and refusing or revoking patent if the application does not disclose or wrongly mention the source of origin. ${ }^{8}$ Brazil also issued regulation relating to the indication of the origin of genetic material in patent application under Government Resolution No.134/2006, which provides mandatory identification whether the subject matter of patent application refers to samples of Brazilian genetic heritage or not. Furthermore, Philippines has also issued the Executive Order 247 regarding Prescribing Guidelines on Establishing a Regulatory Framework for the Prospecting of Biological and Genetic Resources, Their by-Products and Derivatives, for Scientific and Commercial Purposes and for Other Purposes (entered into force on 18 May 1995).

\footnotetext{
${ }^{6}$ See several examples of national legislative and regulatory framework such as Bolivia Supreme Decree No. 24676 Regulating Decision 391 on the Common Regime for Access to Genetic Resources (entered into force on 21 June 1997); Brazilian Medida provisório sobre o acesso ao patrimônio genético (Provisional Measure Number 2168 on Access to Genetic Resources and Traditional Knowledge of Brazil) 16 August 2001.

7 The United Nations Convention on Biological Diversity (CBD) done at Rio de Janeiro, 5 June 1992, 31 ILM 822, opened for signature 5 June 1992 (entered into force 29 December 1993). Text and information on the CBD can be found at the site of the Secretariat of the Convention on Biological Diversity, 'UNEP (CBD Secretariat), The Rio Declaration, UN.Doc.A/CONF.151/5/Rev.1' (CBD Secretariat, 1992) <http://www.cbd.int/convention/convention.shtml $>$.

${ }^{8}$ Indian Patent (Amendment) Act, 2005 known as the Third Patents Amendment (entered into force on 1 January 2005. The Gazette of India Number 18 on 5 April 2005., available from WIPO, 'WIPO Collection of Laws for Electronic Access' (WIPO) < http://www.wipo.int/clea/en/text_pdf. jsp?lang=EN\&id=2407> accessed 23 March 2019.
} 
After 15 (fifteen) years entered into force, the Act was amended again in 2016 into the new Act Number 13 of 2016 regarding Patent. ${ }^{9}$ Surprisingly, one of the most substantial reasons for such amendment was the intensified pressures to fully compliance with TRIPs obligation and the awareness to support access and benefit sharing (ABS), prior informed consent (PIC) provided by the CBD. ${ }^{10}$ Indonesia has realised that its GRTK has been utilised by others to develop new and useful inventions, but this country received nothing for such utilization. ${ }^{11}$ Accordingly, this new Act has an objective to synergise the TRIPs Agreement and the CBD objectives.

Based on the above background, this research analyses the compatibility of Indonesia's policy on the patentability of GRTK with the TRIPs Agreement and the CBD. The focus on this analysis is whether patenting GRTK has satisfied the patentability thresholds of novelty, inventive step and industrial applicability in Indonesia. It also analyses whether such patent does not excluded from patentabilty due to contrary to prevailing laws, morality, public order as stipulated under Article 9 of the Indonesian Patent Act. Furthermore, this research also analyses to what extend the principles of CBD such as Prior Informed Consent (PIC), Disclosure of Origin and Benefit Sharing has been accommodated in this Patent Act. Lastly, this research examines the sufficiency of the Patent Act to accommodate the richness of this country on GRTK and whether the Act provides sufficient policy which enables Indonesia to gain benefit from the existing Patent Act to protect GRTK.

\section{The Patentability on GRTK under Indonesian Patent Act}

Similar to the Patent Act of 2001, fundamental basis of the Indonesian Patent Act of 2016 provides protection for inventions related to genetic resources and technologies as long as they fulfil the requirements of patentability enshrined under Article 3 (1) of the Act, namely novely, involve inventif step and industrial

9 The Act of the Republic of Indonesia Number 13 Year 2016 about Patent (The State Gazette of the Republic of Indonesia Number 176 of 2016, Supplementary State Gazette Number 5922), known as The Indonesian Patent Act of 2016.

${ }^{10}$ See Explanatory Memoranda of the Indonesian Patent Act of 2016, General, para. 5.

11 ibid. 
applicability. ${ }^{12}$ By providing those requirements mean that the substance of the Patent Act of 2016 is more or less similar to the TRIPs Agreement. Interestingly, this Act does not use the Indonesian term of invention called 'penemuan' (Indonesian language) anymore, unlike the previous Act. It uses the term 'invensi' as a conversion of the foreign language term 'invention'. ${ }^{13}$ Further, unlike the TRIPs Agreement and the Paris Convention ${ }^{14}$ which do not define what 'invention' is, this national law has specified the definition of 'invensi' or invention as stipulated under Article 1 (2). Invention means "an inventor's idea poured in any activities of solving a specific problem in the field of technology, either in the form of a product or process, or an improvement and development of a product or a process". It means that Indonesia adopts broader concept of invention.

The Act and its explanatory memoranda also do not provide a definition of the term 'technology'. This is different from the first Indonesia Patent Act which defined 'technology' as equivalent to 'science in the field of industry', produced as a result of research and development (R \& D) efforts' ${ }^{15}$ In the absence of such a specified definition of 'technology' under this new Act suggests that Indonesia has adopted a broad flexible concept of technology comprising all technologies, including modern biotechnological inventions provided that they satisfied the requirements of patentability. This adoption indicates two aspects. Firstly, Indonesia follows the TRIPs Agreement which requires Member nations to comply with a wide concept of industrial property referred to the Paris Convention Article $1,{ }^{16}$ and secondly, to support the development of any kind of technology in Indonesia. Considering the second aspect, arguably, that adoption of broader approach of invention is probably sensible for the purpose of enhancing $R \& D$ activities in a developing country like Indonesia.

12 See Article 3 of the Indonesian Patent Act of 2006.

${ }_{13}$ See Articles 1 (2) of the Indonesian Patent Act of 2016.

14 The Paris Convention for the Protection of Industrial Property, 21 U.S.T. 1583, 828 U.N.T.S. 305. 20 March 1883 (entered into force 26 April or 19 May, 1970).

15 See the Explanatory Memoranda of the Indonesian Patent Act of $1989 .$.

${ }^{16}$ The TRIPs Agreement obligates all the WTO Member Nations to comply with the Paris Convention as revised in 1967 in Stockholm, Articles 1 to 12 and 19. See Article 2(1) of the TRIPs Agreement;; See also, Carlos M Correa, 'Patent Right', International Property and International Trade, The TRIPs Agreement (Correa and, Kluwer Law International, The Netherlands 2008).[189]. 


\section{Patentability Thresholds}

The patentability thresholds under the Indonesian Patent Act are similar with other jurisdictions which implement the TRIPs Agreement. As mentioned earlier that the Act provides that a patent may only be granted for an 'invention' that is 'novel', has an 'inventive step' and is 'capable of industrial application', ${ }^{17}$ in the field of technology, except for inventions falling under exceptions stipulated in the Article 9. Article 9 of the Indonesian Patent Act of 2016 provides that,Inventions that are not patentable include:

a. any process or product of which the announcement and use or the implementation contravenes the prevailing rules and regulations, religious morality, public order or ethics;

b. any method of examination, treatment, medication, and or/surgery applied to humans and/or animals;

c. any theory and method in the field of science and mathematics;

d. all living creatures, except micro-organism, or

e. any biological process which is essential in producing plant or animal, except non-biological process or microbiological process.

Based on these thresholds of novelty, inventiveness and industrial applicability, biotechnological inventions are protected, irrespective of whether such inventions are derived from GRTK of other countries of origin. In the absence of a specific reference to invention related to GRTK under Indonesian legal documents and literatures, it can be construed that the requirements of such inventions are the same as those that apply to patent for other types of technological inventions. Because of that, it is important to examine the (3) three patentability thresholds in the context of biotechnological inventions related to GRTK.

\section{- Novelty of GRTK}

The criterion of novelty is determined by both Articles 5 and 6 of the Indonesian Patent Act. An invention is regarded as 'novel' if at the first time of the Filing Date of the application the invention claimed is 'not the same' with the any 'previously disclosed technology'. ${ }^{18}$ The term 'not the same' according to the Act does not mean

\footnotetext{
${ }^{17}$ Article 3 (1) of the Indonesian Patent Act of 2016.

18 Article 5 (1) of the Indonesia Patent Act of 2016.
} 
that the inventions must be different only, but shall also be different in technical characteristic of its function compared to the technical characteristics of previous invention. ${ }^{19}$ The term 'previously disclosed technology' is equivalent to the term 'state of the art' or 'prior art'which covers patent literatures and non-patent literatures.

The 'previously disclosed technology' is a technology which has been 'announced' in Indonesia or abroad in writing, oral explanation or demonstration or other means which make it possible for a skilled person to implement the invention prior to the Filing Date and the Priority Date. ${ }^{20}$ Based on this definition, oral traditional knowledge can be considered as 'prior art', and consequently, inventions related to GRTK derived from oral traditional knowledge cannot be patented in Indonesia. However, written evidence is required under the Act for oral explanation, demonstration and in other means irrespective of whether it is conducted in Indonesia or overseas. ${ }^{21}$ This last requirement inhibits the application of oral traditional knowledge as 'prior art'. Accordingly, as long as there is no written evidence, oral traditional knowledge is novel for the purpose of patent protection in Indonesia.

Furthermore, under new Act, the 'substantive examination' is not only to examine 3 (three) decisive factors of patentability (novelty, inventive step and industrial applicability), but also include assessment of the unity and adequate disclosure of the invention and ensuring that such proposed invention is not deemed as unpatentable. Unfortunately, although adequate disclosure and transparency are very important, it is uneasy for patent examiners to assess the origin of GRTK in the invention during examination process, or other problems related to genetic resources, like morality and so forth. Usually, patent examiners assess patentability thresholds only and because of that it is almost unlikely to prevent the misappropriation use of GRTK through Patent Office in Indonesia during the examinations process.

19 The Explanatory Memoranda of the Indonesian Patent Act of 2016, Article 5(1).; See also Patrick Keyser, Intellectual Property in Indonesia, Analysis of Recent Statutory Reform (Ratio Book, New South Wales 2001).[23].

${ }^{20}$ Article 5 (2) of the Indonesian Patent Act of 2016.

${ }^{21}$ The Explanatory Memoranda of the Indonesian Patent Act of 2016, Article 5 (2). 
The Act also specified that an invention is not deemed as announced if within the term of maximal 6 (six) months, the inventor has been exploiting the invention in Indonesia for the objectives of $\mathrm{R} \& \mathrm{D}$ experimentation, thesis and dissertation defences, and other scientific meetings to discuss research result in the universities. ${ }^{22}$ Furthermore, an invention is also deemed not to be 'announced' if within the term of 12 (twelve) months before the Filing Date any other person disclosed it by breaching an obligation to keep the invention confidential. ${ }^{23}$ Antons observed that this provision is apparently motivated by the doctrine of confidential information which exists in Anglo-American nations and such a doctrine is new under the Indonesian legal system, ${ }^{24}$ although a specific law of trade secrets has been enacted in Indonesia. ${ }^{25}$

The new Indonesian Patent Act also clearly follows the generally understood and widely adopted rule of patentability that 'discovery' is different to 'invention'. This new Act distinguishes between 'invention' and 'discovery', and patent is only for 'invention', not for 'discovery'. Falls within the scope of 'discovery' are the new uses of known products and new forms of existing compounds that do not result in the increase of efficacy, which has been known from such compounds. ${ }^{26}$ This concept is very important for genetic resources, because it implies that the existence of genetic material in nature might be regarded as not novel for the purpose of patent law and accordingly not an 'invention'. However, if the claimed invention is new in the sense that it has not been previously publicly available as explained above, it would probably satisfy the novelty requirement under the Act.

\footnotetext{
${ }^{22}$ Article 6 (b) (c) of the Indonesia Patent Act of 2016.

${ }^{23}$ Article 6(2) of the Indonesian Patent Act of 2016.

${ }^{24}$ Christoph Antons, Intellectual Property Law in Indonesia (Kluwer Law International, the Hague 2000).[140-141].

${ }^{25}$ See The Act of the Republic of Indonesia Number 30 of 2000 about Trade Secret (State Gazetteof the Republic of Indonesia Number 242 of 2000, Supplementary State Gazette Number 4044).

${ }^{26}$ Article 4 (f) of the Indonesian Patent Act of 2016.
} 


\section{- Inventive Step of GRTK}

An invention is regarded as having an inventive step if it does not constitute something that is obvious to "a person skilled in the art" (expertise = keahlian in Indonesian). ${ }^{27}$ The assessment of obviousness of an invention shall be made by taking into account "the state of the art" at the time of filing the application in case the application is filed on the basis of Priority Right or which has existed at the time of filing the first patent application. ${ }^{28}$

However, it is still unclear whether techniques or isolation processes of genetic material or resources, including DNA sequences satisfy the requirement of inventive step under the new Indonesian Patent Act. This question needs to be ascertained by taking into account a number of different perspectives in line with Indonesian national and technological interests. Experts argued that due to the advanced development in DNA sequencing technologies, isolating genetic sequences can probably be regarded as a routine process and no longer regarded as inventive. ${ }^{29}$

It is worthy to note that in the case of processes and techniques of isolation of genetic material and sequences, different jurisdictions apply different approaches. ${ }^{30}$

27 Article 7 of the Indonesian Patent Act of 2016.

${ }^{28}$ Article 7 (2) of the Indonesian Patent Act of 2016.. Then, the Explanatory Memoranda of the Article 7 (2) clarifies that the meaning of the 'first patent application is filed on the basis of Priority Rights' is the first application proposed in other Paris Convention countries or the WTO Member country. It seems that this Explanatory Memoranda reaffirmed the consistency of Indonesia with Paris Convention.

${ }^{29}$ See for example the opinion of nuffieldbioehics.org, 'Nuffield Council on Bioethics on The Ethic of Patenting DNA' (nuffieldbioehics.org, 2002) <http://http//www.nuffieldbioehics.org> accessed 9 April 2018.[29].

${ }^{30}$ See for example, some jurisdictions like European Patent Office (EPO), the US and Australia applies different approach in respect of Patenting DNA sequence technology. The EPO considered that isolation of genetic sequence is inadequate to meet the 'inventive step' requirement. See the European Patent Office, Japan Patent office and The United States Patent and Trademark Office, Trilateral Project B3b: Mutual Understanding in Search and Examination -Report on Comparative Study on Biotechnology Patent practices (2001), Trilateral Project, San Francisco, Annex 2, 43. See also nuffieldbioehics.org, 'The Nuffield Council on Bioethics, The Ethics of Patenting DNA' (nuffieldbioehics.org, 2002) <http://http//www.nuffieldbioehics.org > accessed 9 April 2016. While in Australia, IP Australia takes the view that in order to meet the inventive step assessment, biological material related inventions mush involve 'the technical intervention of a technologist applying their inventive ingenuity to produce something distinguishable from natural source material. See IP Australia, 'Australian Patents for; Microorganisms; Cell Lines; Hybridomas; Related Biological Materials and Their Use; \& Genetically Manipulated Organisms, Commonwealth of Australia' (IP Australia, 2003) <http://www.ipaustralia.gov.au/pdfs/patents/specific/biotech.pdf $>$ accessed 9 April 2018. 
As a developing country, where the development of the biotechnology industry is still not as advanced as the developed countries, the Indonesia's approach in this respect should consider the balance between the need to facilitate the development of biotechnology industry and the people's need to 'enjoy the benefits of scientific progress and its application'. ${ }^{31}$ Industrial Applicability of GRTK

The term of "industrial applicability" was a subject to question since the previous Patent Act of 2001. Philip Griffith commented that the explanation of ‘industrial applicability' under Indonesian Patent Act did not provide clear direction. ${ }^{32}$ Griffith predicted that the meaning of the term will be determined on a case by case basis at the examination step and in revocation proceedings in the Commercial Court. ${ }^{33}$ Griffith also analysed that this "industrial applicability" requirement under the Indonesian Patent Act has been deliberately kept broad because it is difficult to estimate what kinds of new innovations and technologies will appear and prove to be useful and "what new forms of commercial and industrial uses might be found for those new developments or inventions". ${ }^{34}$ In the context of DNA sequence technologies and the isolation of genetic resources and material, if "industrial applicability" is to be broadly interpreted, it means that those technologies and isolation techniques would be regarded as satisfying the "industrial applicability" requirement under the Indonesian Patent Act.

\section{Exceptions to Patentability}

\section{- Inventions Contrary to Prevailing Regulations, Public Order and Morality}

The Indonesian Patent Act states that a patent shall not be granted to an invention regarding: "Any process or product of which the announcement and use or implementation contravenes the prevailing legislations, religion, public order

\footnotetext{
${ }^{31}$ See United Nations International Covenant on Economic, Social and Cultural Rights (ICESRC) International Covenant on Economic, Social and Cultural Rights (ICESRC) opened for signature 16 December 1996, 999 UNTS 3 (entered into force on 3 January 1976), Articl.

${ }^{32}$ Philip Griffith, 'Patent Law in Indonesia, Paper Presented at Intellectual Property Rights Training Course of Indonesia Australia Specialised Training Project (IASTP)'.[9].

33 ibid.

34 ibid.
} 
or morality". ${ }^{35}$ This Article exhibits a general and wide concept in accordance with the Article 27 (2) of the TRIPs Agreement. The problem is that there is no such manual in Indonesia, or even an Explanatory Memoranda does not provide an explanation of what kind of inventions can be categorised as "contravene prevailing legislations". In determining whether an invention contravenes "prevailing legislations" in the absence of a patent manual is by looking at written specifications and claims. A person who wants a patent should write specifications and claims which describe the legal purpose of the invention, and not refer to illegal uses or forms of the invention. However, it would still be valuable and useful to provide a clear explanation to verify what kind of legislation can be used to defeat the patentability.

\section{- Inventions on Method of Examination, Treatment, Medication or Surgery for Human and Animal}

The new Indonesian Patent Act provides that methods of examination, treatment, medication and/or surgery applied to human and animal are not patentable. ${ }^{36}$ The basis for this exception is unclear, as the Act does not provide further explanation, but presumably a notion about ethics and perceived morality of the public health issues. ${ }^{37}$ This exception is permissible under the TRIPs Agreement based on the public health consideration.

It is perceived that this Article only applies to methods of treatment, but not to medical equipment, devices, and drugs as important elements of treatment. Accordingly, whether or not an invention is patentable under this provision depends very much on the claim. If the claim is for patented process such as method for treatment, it would be unpatentable, but if the claim is for a product, it would be patentable. This exception is similar to the patent legislation in other jurisdictions

\footnotetext{
${ }^{35}$ Article 9 (a) of the Indonesian Patent Act of 2016.

${ }^{36}$ Article 9 (b) of the Indonesian Patent Act of 2016.

37 See Article 27 (3) of the TRIPs Agreement.
} 
like the Patent Act 1977 of the United Kingdom, ${ }^{38}$ Canada, ${ }^{39}$ and New Zealand. ${ }^{40}$ In contrast, Australia implements the different approach that methods of medical treatment are patentable inventions. ${ }^{41}$

\section{- All Living Creatures: Except Micro-organism}

Living creatures are not patentable under the Indonesian Patent Act, except micro-organisms. ${ }^{42}$ These living creatures include human beings, animals or plants. The non-patentability of inventions on living creatures in this new Act accommodates society's demands, which argues that such a patent would contravene religion, morality, and ethics. However, this Act is silent in respect of patenting genes. Indeed, it is not clear whether a living organism such as gene can be patented or not under the Indonesian Patent Act.

In the absence of any further reference, genes can be patented in Indonesia. It can be interpreted that what is excluded from patentability under Indonesian Patent Act is 'human being, animal or plant as a whole'. It can be argued that a part, including genes are subject to patent protection, and plant variety also subject to Plant Varieties Protection (PVP). This exclusion is one which has provoked crucial concerns in the public debate about IPRs in the early 2000 in

${ }^{38}$ The Patent Act 1997, Section 4(2) of the United Kingdom.stipulates that: An invention of a method of treatment of the human or animal body by surgery or therapy or of diagnosis practised on the human or animal body shall not be taken to be capable of industrial application.

39 The Patent Office of Canada clearly. stipulates that an invention related to a process of surgery or therapy on living human does not fall under the scope of 'invention' according to Canadian Patent Act of 1985 Section 2., and accordingly they do not fulfil the utility criteria. See Canadian Biotechnology Advisory Committee, 'Patenting of Higher Life Forms and Related Issues'., Report to the Government of Canada, 'Biotechnology Ministerial Coordinating Committee' (Government of Canada, 2002) <http://www.cbac-cccb.ca $>$ accessed 8 April 2016.See also in general, Catherine Geci and Bartha Maria Knoppers, 'Patenting of Higher Life Forms; A Canadian Perspective', Intellectual Property and Biological Resources (Burton Ong, Marshall Cavendish Academic 2004).[163-184].

${ }^{40}$ This exclusion is based on the Decision of Welcome Foundation Ltd v. Commissioner of Patents (1983) 2 NZLR 385. This case argued that methods of medical treatment are not patentable on the ground that they are not considered as a 'manner of manufacture'.

${ }_{41}$ The significant case is Bristol Myers Scuibb Company v FH Faulding and Co Ltd (2000) 97 FCR Federal Court of Australia. The Decision on this case confirmed the position of the Full Federal Court Decision in Anaesthetic Supplies Pty Ltd v Rescare Ltd (1994) 28 IPR 383. Based on the case decisions, it can be concluded that the Australian Patent Office is in the position to grant a patent regarding the methods of treatment of human Body. See further in Kathy Bowrey and Philip Griffith Jill McKeough, Intellectual Property; Commentary and Materials (4th edn, Lawbook Co 2007).[314].

${ }^{42}$ Article 9 (d) of the Indonesian Patent Act of 2016. 
Indonesia on the basis that patents for such subject matters contravene ethics, religion, and culture of Indonesian values. ${ }^{43}$ But, such concern does not appear anymore recently.

Furthermore, in the absence of any reference to the patentability of genes under Indonesian Patent Act, means that it can be interpreted broadly and narrowly, as Subroto and Suprapedi from the IPRs Centre of the Indonesian Science Agency (LIPI) states that: "computer models and related simulations, germ plasmas, cultures, cell sequences, plant, part of plant, seeds, pollen, protein, peptide, metabolite compound, sequence DNA and RNA, genes, probe, plasmid and information related to it" are regarded as IP forms. ${ }^{44}$ That argument seems to interpret that the legislation allows that germ plasm, genes, and so forth to be patented. If this interpretation is accurate, the unintended consequences of this loose drafting and lack of analysis may mean that Indonesian patent law is more or less similar to those applied in other developed nations, which follow the principle of "everything under the sun made by man is patentable" except human beings, plants and animals in a whole. This probably as a consequence of lack of clarity of the legislation, but it may also be intentional to enhance the development of biotechnology and industrial application, in particular to increase the number of national patents. If certain types of biotechnological inventions related to genetic resources, particularly part of human being, are patentable under the Indonesian Patent Law, it indicates that what it stated by Antons is clearly accurate, in which he argued that:

43 Hira Jhamtani, '(The WTO, New World's Police)' (Kompas Cyber Media, 2000) $<$ http:208.150.216.210/kompas-cetak/0005/12/OPINI/wato04.htm> accessed 8 April 2016.. See Terranet.or.id, 'Menolak Paten Atas Makhluq Hidup' (Reject Patents on Life Forms), Portal Lingkungan Hidup Dan Pembangunan Berkelanjutan, (The Gate of Environment and Sustainable Development)' (terranet.or.id, 2018) <http://www.terranet.or.id/tulisandetil.php?id=42> accessed 7 April 2018.[77], 2; See also Kompas Cyber Media, 'Indonesia Jangan Terima Paten Makhluq Hidup (Indonesia Must Reject Patent on All Life Form)' (Kompas Cyber Media, 2000) <http://www.kompas.com/kompas-cetak/0007/19/iptek/indo10.htm> accessed 18 April 2018.

${ }_{44}$ M. Ahkam Subroto and Suprapedi, 'Aspek-Aspek Hak Kekayaan Intellectual Dalam Penyusunan Perjanjian Penelitian Dengan Pihak Asing Di Bidang Biologi', (IP Aspects in the Arrangement of Research Agreement with Foreign Party in the Field of Biology) a Paper Presented at Team Coordination Mee' (2001).[6]. 
"In the absence of any reference to the patentability of living organisms means also that the developing country Indonesia takes an extremely liberal approach in this regard even in comparison to most industrialised countries". ${ }^{45}$ (emphasis added)

Critics argue that the patentability of those subject matters will be potentially risky for developing countries due to the country's lack of capacity in biotechnology because it may only facilitates the developed nations to get patent protection for their technological innovations in Indonesia, where the local inventors or society have no capacity to compete. It may not increase the number of national patents since the biotechnological development in Indonesia is still at the level of $R \& D$, or otherwise it may also inhibit R \& D in Indonesia. Certainly, this is extremely imbalanced of biotechnological development in Indonesia compared to the most developed nations should not be used by Indonesia to take the same approach or even a more "liberal" approach. At least, in providing patent protection for biotechnological inventions, Indonesia should regulate with thresholds not more generous than those provided by the most developed nations.

\section{- Essentially Biological Processes for Production of Plant and Animal}

Essentially biological processes for the production of plants and animals are excluded from patentability in Indonesia. ${ }^{46}$ In contrast, non-biological processes or microbiological processes are patentable. ${ }^{47}$ This exception is in accordance with the TRIPs Agreement. ${ }^{48}$ The meaning of "essentially biological process for production of plant or animal" refers to conventional or natural breeding process, like natural transplantation techniques and pollinations. ${ }^{49} \mathrm{~A}$ "non-biological process" or "microbiological process" is defined as transgenic or genetic engineering processes of production of plant or animal which conducted by involvement of chemical process, physics, and the use of micro-organisms or other forms of genetic engineering. ${ }^{50}$ The

\footnotetext{
45 Christoph Antons (n 24).[144].

46 Article 9 (e) of the Indonesian Patent Act of 2016.

47 ibid.

${ }^{48}$ See Article 27. 3. (b) of the TRIPs Agreement..

49 The Explanatory Memoranda of the Indonesian Patent Act of 2016, Article 9 (e) 41.

${ }^{50}$ The Explanatory Memoranda of the Indonesian Patent Act of 2016, Article 9 (e).
} 
basis for granting patents to inventions related to "micro-organism" or "non-biological processes" and "microbiological processes for the production of plant and animal" is due to the advanced development of biotechnology in the recent decades has resulted in various inventions which had significant advantages to society. Accordingly, patent protection is needed to reward such inventions.

\section{PIC, Disclosure of Origin, Benefit Sharing of the CBD under Indonesian Patent Act}

The disclosure of origin and $\mathrm{PIC}^{51}$ is still at the heart of discussion in a number of international and regional forum. Such concepts are developed under the spirit of the $\mathrm{CBD}$, with the main objective to prevent misappropriation use of patent rights and bio-piracy. In the context of PIC, the Article 15 (5) of the CBD stipulates that "Access to genetic resources shall be subject to prior informed consent of the Contracting Party providing such resources, unless otherwise determined by the Party".

Twenty years ago, several rich biodiversity countries have already amended their patent law by adding disclosure of origin requirement and PIC as a prerequisite for granting patents on biotechnological inventions including inventions related to GRTK. ${ }^{52}$ Sadly, although Indonesia is categorised as one of the mega biodiversity countries, such requirements did not exist under the Indonesian Patent Act of 2001. Surprisingly, the new Act provides provisions on disclosure requirement and benefit sharing. Under this new Act, the nature of disclosure of origin requirement is mandatory, as Article 26 (1) clearly stipulates that "if invention related to and/or derived from genetic resources and/ traditional knowledge, shall clearly and accurately mention the origin of such GRTK in the patent description". The reason for mentioning such source of origin in the patent description is to prevent the claim of such resources and knowledge by other nations, and to support access and benefit sharing. ${ }^{53}$

${ }^{51}$ The United Nations Environmental Program (UNEP) defines PIC to an activity that is given after receiving full disclosure regarding the reasons for the activity, the specific procedures the activity would entail, the potential risk involved, and the full implications that can realistically be foreseen. See UNEP doc. UNEP/CBD/TKBD/1/2, Oct 18, 1997.[26].

52 See Indian Patents (Amendments) Act, 2002 section 10 (d) and so forth.

53 The Explanatory Memoranda of the Indonesian Patent Act of 2016, Article 26 (1). 
Nevertheless, if patent derived from genetic resources and or traditional knowledge does not fulfil the disclosure requirement, such patent can be abolished through lawsuit filed by a third party to sue the patent holder at Commercial Court. ${ }^{54}$ Then, Patent can be abolished based on Commercial Court Decision. Reading the Article 132 of the new Patent Act means that the abolition of the patent claim is directed to the patent holder, and not to the Government that passed the granting of the patent.

This new Patent Act recognises the concept of benefit sharing stipulated under the CBD. Article 26 (3) states that benefit sharing and access to use GRTK are conducted in accordance with legislation and international treaty that has ratified by Indonesia in the area of GRTK. Although benefit sharing is one of the most important aspects of the CBD, it does not mean that patent law shall regulate it. If invention use of GRTK, the inventor should has access license and agreement of benefit sharing with the country of the origin of such resources whether in the form of Bio-Partnership, Material Transfer Agreements (MTAs), or any other forms. This matter should be separately regulated by relevant legislations, like Management of Genetic Resources Act or other sui generis Act.

Based on the above provisions, it can be seen that the approach adopted by Indonesia under the new Patent Act on disclosure requirement is in accordance with Indonesia's position at international forums that supports amendment of the TRIPs Agreement to accommodate the principles of PIC, disclosure of origin of genetic resources and benefit sharing. In this context, the Indonesian Government realises that Indonesia has an important position in terms of global biodiversity, and this country is also rich with traditional knowledge growing in traditional communities throughout Indonesia. These valuable resources, should be wisely exploited for the benefit of the communities and the State, while the sustainable and conservation of environment should also be maintained for future generation.

54 Article 132 (1) b of the Indonesian Patent Act of 2016. 


\section{Conclusion}

The new Indonesian Patent Act is drafted as a direct interpretation to the TRIPs Agreement and adopted some developed nation legislations on patents especially for substantial aspects, like patentability thresholds, exceptions from patentable inventions, the concept of invention, and the patentability of inventions related to GRTK. Even though in those areas the TRIPs Agreement provides some flexible room for interpretation in line with the level of biotechnological development, Indonesia does not use this opportunity. Otherwise, there is an indication that Indonesia has adopted a similar approach to other developed nations or even overly liberal approach which more suited to a country with greater degree of economic and biotechnological development. Because of that, the new Indonesian Patent Act of 2016 is still insufficient to deal with patentability of GRTK and the development of biotechnology industry in Indonesia. It is uneasy for GRTK to fulfil the patentability thresholds of novelty and inventiveness under Indonesian Patent Act and the patentability on genes is still unclear.

The new Indonesian Patent Act also still insufficient to accommodate both the richness of this country on GRTK and the level of biotechnological development of Indonesia. Because of that, it is uneasy for this country to gain benefit from the existing of new Patent Act to utilize the richness of GRTK since the level of biotechnological development is not as advanced as developed nations. But the substance of the new Indonesian Patent Act is similar to the Patent Acts of many developed countries which are advanced in modern biotechnology industry.

\section{Bibliography}

Act of the Republic of Indonesia Number 13 of 1997.

Act of the Republic of Indonesia Number 13 Year 2016 about Patent (The State Gazette of the Republic of Indonesia Number 176 of 2016, Supplementary State Gazette Number 5922), known as The Indonesian Patent Act of 2016.

Act of the Republic of Indonesia Number 14 Year 2001 about Patent (the State Gazette of the Republic of Indonesia Number 109 of 2001, Supplementary State Gazette Number 4130). 
Act of the Republic of Indonesia Number 14 Year 2001 regarding Patent (the State Gazette of the Republic of Indonesia Number 109 Year 2001, Supplementary State Gazette Number 4130).

Act of the Republic of Indonesia Number 30 of 2000 about Trade Secret (State

Gazetteof the Republic of Indonesia Number 242 of 2000, Supplementary State Gazette Number 4044).

Act of the Republic of Indonesia Number 6 of 1989 regarding Patent (State

Gazette of the Republic of Indonesia Number 39 Year 1989).

Article 132 (1) b of the Indonesian Patent Act of 2016.

Article 27. 3. (b) of the TRIPs Agreement.

Article 27 (3) of the TRIPs Agreement.

Article 3 (1) of the Indonesian Patent Act of 2016.

Article 3 of the Indonesian Patent Act of 2006.

Article 4 (f) of the Indonesian Patent Act of 2016.

Article 5 (1) of the Indonesia Patent Act of 2016.

Article 5 (2) of the Indonesian Patent Act of 2016.

Article 6(2) of the Indonesian Patent Act of 2016.

Article 6 (b) (c) of the Indonesia Patent Act of 2016.

Article 7 (2) of the Indonesian Patent Act of 2016.

Article 7 of the Indonesian Patent Act of 2016.

Article 9 (a) of the Indonesian Patent Act of 2016.

Article 9 (b) of the Indonesian Patent Act of 2016.

Article 9 (d) of the Indonesian Patent Act of 2016.

Article 9 (e) of the Indonesian Patent Act of 2016.

Articles 1 (2) of the Indonesian Patent Act of 2016. 
Canadian Biotechnology Advisory Committee, 'Patenting of Higher Life Forms and Related Issues'.

Canadian Patent Act of 1985 Section 2.

Carlos M Correa, 'Patent Right', International Property and International Trade, The TRIPs Agreement (Correa and, Kluwer Law International, The Netherlands 2008).

Catherine Geci and Bartha Maria Knoppers, 'Patenting of Higher Life Forms; A Canadian Perspective', Intellectual Property and Biological Resources (Burton Ong, Marshall Cavendish Academic 2004).

Christoph Antons, Intellectual Property Law in Indonesia (Kluwer Law International, the Hague 2000).

Government of Canada, 'Biotechnology Ministerial Coordinating Committee' (Government of Canada, 2002) <http://www.cbac-cccb.ca $>$ accessed 8 April 2016.

Hira Jhamtani, '(The WTO, New World's Police)' (Kompas Cyber Media, 2000) <http:208.150.216.210/kompas-cetak/0005/12/OPINI/wato04.htm> accessed 8 April 2016.

Indian Patent (Amendment) Act, 2005 known as the Third Patents Amendment (entered into force on 1 January 2005.

Indian Patents (Amendments) Act, 2002 section 10 (d) and so forth.

Intergovernmental Committee on Genetic Resources, 'Traditional Knowledge and Folklore (IGCGRTKF) of World Intellectual Property Organization (WIPO)' (2000).

IP Australia, 'Australian Patents for; Microorganisms; Cell Lines; Hybridomas; Related Biological Materials and Their Use; \& Genetically Manipulated Organisms, Commonwealth of Australia' (IP Australia, 2003) < http://www. ipaustralia.gov.au/pdfs/patents/specific/biotech.pdf $>$ accessed 9 April 2018.

Jill McKeough KB and PG, Intellectual Property; Commentary and Materials (4th edn, Lawbook Co 2007).

Kompas Cyber Media, 'Indonesia Jangan Terima Paten Makhluq Hidup (Indonesia Must Reject Patent on All Life Form)' (Kompas Cyber Media, 2000) <http://www.kompas.com/kompas-cetak/0007/19/iptek/indo10.htm> accessed 18 April 2018. 
M. Ahkam Subroto and Suprapedi, 'Aspek-Aspek Hak Kekayaan Intellectual Dalam Penyusunan Perjanjian Penelitian Dengan Pihak Asing Di Bidang Biologi', (IP Aspects in the Arrangement of Research Agreement with Foreign Party in the Field of Biology) a Paper Presented at Team Coordination Mee' (2001).

Memoranda of the Article 7 (2) clarifies that the meaning of the 'first patent application is filed on the basis of Priority Rights' is the first application proposed in other Paris Convention countries or the WTO Member country.

Memoranda of the Indonesian Patent Act of 1989.

Memoranda of the Indonesian Patent Act of 2016, Article 26 (1).

Memoranda of the Indonesian Patent Act of 2016, Article 5(1).

Memoranda of the Indonesian Patent Act of 2016, Article 5 (2).

Memoranda of the Indonesian Patent Act of 2016, Article 9 (e).

Memoranda of the Indonesian Patent Act of 2016, Article 9 (e) 41.

Memoranda of the Indonesian Patent Act of 2016, General, para. 5.

Memoranda reaffirmed the consistency of Indonesia with Paris Convention The Gazette of India Number 18 on 5 April 2005.

nuffieldbioehics.org, 'Nuffield Council on Bioethics on The Ethic of Patenting DNA' (nuffieldbioehics.org, 2002) < http://http//www.nuffieldbioehics.org > accessed 9 April 2018.

- ' 'The Nuffield Council on Bioethics, The Ethics of Patenting DNA' (nuffieldbioehics.org, 2002) <http://http//www.nuffieldbioehics.org $>$ accessed 9 April 2016.

Patrick Keyser, Intellectual Property in Indonesia, Analysis of Recent Statutory Reform (Ratio Book, New South Wales 2001).

Philip Griffith, 'Patent Law in Indonesia, Paper Presented at Intellectual Property Rights Training Course of Indonesia Australia Specialised Training Project (IASTP)'.

Secretariat-WIPO General Assembly, 'Matter Concerning Intellectual Property and Genetic Resources, Traditional Knowledge, and Folklore' (2000). 
Secretariat of the Convention on Biological Diversity, 'UNEP (CBD Secretariat), The Rio Declaration, UN.Doc.A/CONF.151/5/Rev.1' (CBD Secretariat, 1992) $<$ http://www.cbd.int/convention/convention.shtml $>$.

Terranet.or.id, 'Menolak Paten Atas Makhluq Hidup' (Reject Patents on Life Forms), Portal Lingkungan Hidup Dan Pembangunan Berkelanjutan, (The Gate of Environment and Sustainable Development)' (terranet.or.id, 2018) $<$ http://www.terranet.or.id/tulisandetil.php?id=42> accessed 7 April 2018.

The Paris Convention for the Protection of Industrial Property, 21 U.S.T. 1583, 828 U.N.T.S. 305. 20 March 1883 (entered into force 26 April or 19 May, 1970).

The Patent Act 1997, Section 4(2) of the United Kingdom.

The Patent Office of Canada clearly.

The TRIPs Agreement obligates all the WTO Member Nations to comply with the Paris Convention as revised in 1967 in Stockholm, Articles 1 to 12 and 19. See Article 2(1) of the TRIPs Agreement.

UNEP doc. UNEP/CBD/TKBD/1/2, Oct 18, 1997.

United Nations International Covenant on Economic, Social and Cultural Rights (ICESRC) International Covenant on Economic, Social and Cultural Rights (ICESRC) opened for signature 16 December 1996, 999 UNTS 3 (entered into force on 3 January 1976).

WIPO, 'WIPO Collection of Laws for Electronic Access' (WIPO)

$<$ http://www.wipo.int/clea/en/text_pdf.jsp?lang=EN\&id=2407> accessed 23 March 2019.

World Trade Organization, Agreement on Trade Related Aspects of Intellectual Property Rights (TRIPs) of 1994. Marrakesh Agreement Establishing the World Trade Organization, , Annex 1C, Legal Instruments - Results of the Uruguay Round Vol. 31; 33 I.L.M. 1197, 1201, 15 April 1994 (E (1994).

HOW TO CITE: Nurul Barizah, 'Indonesia's Patent Policy on the Protection of Genetic Resources Related Traditional Knowledge: is it a Synergy to Fulfill the TRIPs Agreement and CBD Compliance?' (2020) 35 Yuridika. 
--This page is intentionally left blank-- 